\title{
The Role of Education in Reducing the Disposal Costs of Anesthesia-Related Medical Wastes
}

öz

Amaç: Genel atığın küçük bir bölümünü oluştursa da tıbbi atık yönetimi hem çevresel etkileri hem de maliyeti nedeniyle önemlidir. Tıbbi atık miktarının azaltılması, geri dönüşüm atık miktarının arttırılmasında eğitim ve farkındalık yaratmak en önemli adımlardandır. Bu çalışmanın birincil amacı, anesteziye ait tıbbi atıkların maliyetini azaltmada eğitimin rolünü belirlemek, ikincil amacı ise, kullanılan eğitim materyallerinin geliştirilmesi için veriler sağlamaktır.

Yöntem: Genel anestezi verilen 22 ameliyat salonu ve 3 uyandırma ünitesinin anesteziye ait atıkları değerlendirmeye alındı. Yirmi altı anestezi uzmanı, 37 anestezi teknisyeni, 30 anestezi asistanına haber vermeden, anesteziye ait atıklar gün bitiminde toplanıp tartıldı. Ikinci gün, "Güvenli Tıbbi Atık Yönetimi Kılavuzu" kullanılarak hazırlanmış video linki katılımcılarla paylaşılarak izlemeleri ve sonrasında hazırlanan anketi yanıtlamaları istendi. Eğitim sonrası atıklar yine toplanıp tartıldı. $3.50 \mathrm{TL} \mathrm{kg}^{-1}$ (KDV hariç) olarak belirlenmiş olan tıbbi atık bertaraf maliyeti üzerinden yaklaşık yıllık tasarruf bedeli hesaplandı.

Bulgular: Eğitim öncesi anesteziye ait atık miktarı, 57 olgu için toplam 36.90 kg, eğitim sonrası 64 olgu için toplam $43.36 \mathrm{~kg}$ 'dı. Tıbbi atık miktarı, eğitim öncesi olgu başı miktar, $461.2 \mathrm{~g}$, eğitim sonrası olgu başı miktar, $453.8 \mathrm{~g}$ olarak tartıldı. Tıbbi atık miktarının istatistiksel olarak anlamlı olmasa da azaldığı görüldü ( $p=0.949)$. Tıbbi atık bertaraf maliyeti \%1.6 oranında azaldı. Anestezi ekibinin \%51.3’nün daha önce eğitim aldığı, \%60.4'nün verilen eğitimden yararlandıkları öğrenildi. Sonuç: Eğitim ile tıbbi atık miktarı azaltılabilir. Kliniğimizde atık tasnifi ile ilgili farkındalık olmakla birlikte tıbbi atık miktarının azaltılması için düzenli eğitimlerin yapılması gerektiği düşüncesindeyiz.

Anahtar kelimeler: Anestezi, eğitim, tıbbi atık, sıfır atık, sürdürülebilirlik

\section{ABSTRACT}

Objective: Although it constitutes a small part of the general waste, medical waste management is important both due to its environmental impact and its cost. Creating education and awareness on reducing the amount of medical waste and increasing the amount of waste-recycling are some of the most important steps. The primary purpose of the study is to determine the role of education in reducing the cost of medical waste belonging to anesthesia, and the secondary purpose is to provide data for the development of educational materials used.

Methods: The anesthesia wastes of 22 operating rooms and 3 PACU were evaluated. Anesthetic wastes were collected and weighed at the end of the day without informing 26 anesthesiologists, 37 anesthesia technicians, and 30 anesthesia assistants. On the $2^{\text {nd }}$ day, the education video link was shared with the participants, and afterwards they were asked to watch and answer the questionnaire prepared.The wastes were collected and weighed again after the training. The approximate annual saving cost was calculated over the medical waste disposal cost, which was determined as $3.50 \mathrm{TL} \mathrm{kg}^{-1}$ (excluding VAT).

Results: The amount of anesthesia waste obtained from 22 operating rooms and 3 PACU was $36.90 \mathrm{~kg}$ for 57 cases before training, and $43.36 \mathrm{~kg}$ for 64 cases after training. The amount of medical waste was weighed as $461.2 \mathrm{~g}$ per case before the training, and $453.8 \mathrm{~g}$ per case after the training.It was observed that although not statistically significant, the amount of medical waste decreased ( $p=0.949)$. The cost of medical waste disposal decreased by $1.6 \%$. It was learned that $51.3 \%$ of the anesthesia team had received training before, and $60.4 \%$ benefited from the training provided.

Conclusion: With education, the amount of medical waste can be reduced. Although there is awareness about waste classification in our clinic, we believe that regular training should be done to reduce the amount of medical waste.

Keywords: Anesthesia, education, medical waste, zero waste, sustainability
Received/Geliş: 29 June 2021 Accepted/Kabul: 06 July 2021 Publication date: 16 July 2021

Cite as: Keskin G, Dönmez A. Anestezi ile ilgili thbbi atkların bertaraf maliyetlerini azaltmada eğitimin rolü. JARSS 2021;29(3):178-83.

Gülsen Keskin Sağlık Bilimleri Üniversitesi, Dışkapı Yıldırım Beyazıt Eğitim ve Araştırma Hastanesi, Anesteziyoloji ve Reanimasyon Anabilim Dalı, Ankara, Türkiye

drgulsenkeskin@gmail.com ORCID: 0000-0002-9990-5533

Aslı Dönmez 0000-0002-7378-1632 Sağlık Bilimleri Üniversitesi,

Dışkapı Yıldırım Beyazıt Eğitim ve Araştirma Hastanesi, Anesteziyoloji ve Reanimasyon Anabilim Dalı, Ankara, Türkiye

Bu çalışma, 29-39 Mayıs 2021, VIII. Abant Anestezi e-sempozyumunda, sözlü bildiri olarak sunulmuştur. 


\section{GiRiş}

Tıbbi atıklar genel atığın nispeten küçük bir bölümünü oluştursa da hem çevresel etkileri hem de maliyeti nedeniyle önemlidir. Tıbbi atıklar; sağlık kurumlarının koruyucu, iyileştirici, teşhis ve tedavi gibi tıbbi çalışmaları sırasında üretilen, enfeksiyöz atık, patolojik atık ve delici-kesici atıkları içermektedir. Çalışmalarda, tüm hastane atıklarının yaklaşık \%25'nin ameliyat odası kaynaklı olduğu, ameliyat odası atıklarının da \%25 kadarının anesteziye ait tıbbi atıklar olduğu saptanmıştır ${ }^{(1,2)}$.

Atık yönetiminin en önemli ilkesi atıkları kaynağında doğru olarak ayrıştırmaktır. Tüm hastane atıklarının \%75 ile \%90'ı evsel atıklardır ve çoğu geri dönüştürülme potansiyeline sahiptir ${ }^{(3)}$. Ameliyat odalarında atıkların yanlış ayrıştırılması hem yetersiz geri dönüşüme hem de atığın uygun şekilde işlenmesi ve bertaraf edilmesi için 20 kata kadar daha yüksek maliyetlere neden olmaktadır ${ }^{(4)}$. Atıkların kaynağında doğru şekilde ayrıştırılmamasının nedenleri, kısmen personelin atıkları ayırma gereksinimini yanlış anlamasından, atığın tehlikeli olmayan olarak yanlış bir şekilde ayrıştırı masından dolayı kınanma korkusundan veya eğitim eksikliğinden olabilir. Çalışanların tıbbi atık konusunda farkındalıklarını artıracak eğitim programlarının hazırlanması hem atıkların ayrıştırıması hem de geri dönüşüm konusunda olumlu davranışlar kazanmalarına yardımcı olabilir. Kurumların buna ilişkin yöntemleri geliştirmeleri bertaraf maliyetlerini azaltacaktır. Personelin eğitilmesi de atık üreten kurum ve kuruluşların görev ve sorumluluğundadır.

Çalışmamızın birincil amacı, anesteziye ait tıbbi atıkların miktarını, dolayısıyla atık maliyetini azaltmada eğitimin rolünü belirlemek, ikincil amacı ise, kullanılan eğitim materyallerinin geliştirilmesi için veriler sağlamaktır.

\section{GEREÇ ve YÖNTEM}

Dışkapı Yıldırım Beyazıt Eğitim ve Araştırma Hastanesi Klinik Araştırmalar Etik Kurul onayı (Tarih: 22.03.2021, Karar No. 107/19) alındıktan sonra 22 ameliyat odası ve 3 uyandırma ünitesinin anesteziye ait atıkları prospektif gözlemsel çalışma olarak değerlendirmeye alındı. Bu alanlarda görev yapan 26 anestezi uzmanı, 37 anestezi teknisyeni, 30 anestezi asistanı- na haber vermeden, haftanın ikinci günü tüm çalışma alanlarındaki tıbbi atık, delici-kesici atık ve geri dönüşüm atık kutuları yenilendi ve oda personelinden anesteziye ait atıkların mesai bitimine kadar boşaltılmaması istendi. Mesai bitiminde, her odanın anesteziye ait atıkları genel ve rejyonal uygulama ayrımı yapılmadan dijital tartı (Desis 1E-30 T28 Tek Ekranlı Dijital Terazi) ile tartıldı. Çalışmayı kabul eden katılımcılara bir sonraki gün tıbbi atıklar video linki (Ek 1) verilerek izlemeleri istendi. Eğitimin

EK 1. Eğitim için kullanılan video

https://www.youtube.com/watch?v=fOTdFQIMecA linkinden ulaşılabilen 5 dk. 25 sn süreli, ulusal yayın organı TRT Haber'de yayınlanan Yeşil Adım 8. Bölüm-Tıbbi Atıklar bölümünün, katılımcılardan izlenmesi istenecektir. Sunum, Çevre ve Şehircilik Bakanlığı, Çevre Yönetimi Genel Müdürlüğü, Atk Yönetimi Dairesi Başkanlığı tarafindan hazırlanan Güvenli Tıbbi Atık Yönetimi Kılavuzu (https:// www.csb.gov.tr/gm/cygm) rehberliğinde ve TC. Cumhurbaşkanlığı desteğiyle hazırlanmıştır.

\section{EK 2. Anket Formu}

Anket Formu Anestezi ile İlgili Tıbbi Atkların Maliyetlerini Azaltmada Eğitimin Rolünün Belirlenmesi

Anesteziye ait tıbbi atıkların miktarının video eğitim ile nasıl değişim göstereceğini belirlemek için bu çalışmayı planladık. Eğitim videosunu izlemeniz ve bu soruları cevaplamanız daha sonraki eğitim planlamaları için yol gösterici olacaktır. Katılımınız için teşekkür ederiz.

Yaş-Cinsiyet

Meslek-Mesleki

Tecrübe (YII)

\begin{tabular}{ll}
$\begin{array}{l}\text { Tıbbi Atıklar ile İlgili } \\
\text { Herhangi Bir Eğitim } \\
\text { Aldınız mı? }\end{array}$ & Evet / Hayır \\
\hline İhtiyaç Hissettiniz mi? & Evet / Hayır \\
\hline & A-Gerekli \\
& B-Gereksiz \\
Tıbbi Atıkların Tasnifi ile & C-Zaman Kaybı \\
İlgili Düşünceleriniz & D-Yetişemiyorum \\
Nelerdir? & E-Ulaşamıyorum \\
& F-Zaten Dikkat Ediyorum \\
& G-Diğer....... \\
\hline & A-Uzun Buldum / Kısa Buldum \\
& B-Sıkıcı Buldum / Sıkıcı Bulmadım \\
& C-Yeterli Buldum / Eksik Buldum \\
& D-Faydalandım / Faydalanmadım \\
& E-Yüz Yüze Anlatılmasını Tercih Ederim \\
& F-Anestezi Attkları ile İlgili Davranışları- \\
& mı Değiştirir / Anestezi Atıkları ile İlgili \\
Güvenli Tıbbi Atık & Davranışlarımı Değiştirmez \\
Yönetimi ile İlgili & G-Tekrarlanmasını İsterim / Tekrarlan- \\
Videoyu Nasıl & masına Gerek Yok \\
Değerlendirirsiniz? & H-Diğer........ \\
&
\end{tabular}


ardından katılımcıların demografik verileri, tıbbi atık yönetimi ve eğitim videosu ile ilgili görüşlerini içeren mini anketi yanıtlamaları istendi (Ek 2). Çalışmanın 3. günü (eğitim videosunun izlenmesinden bir gün sonra) yine genel anestezi verilen 22 ameliyat salonu ve 3 uyandırma ünitesinin mesai bitimine kadar olan anesteziye ait atıkları toplandı, tartıldı ve kaydedildi.

Tıbbi Atıkların Kontrolü Yönetmeliği'ne göre oluşturulan ünite içi atık yönetimi planına göre, iğne, bistüri, ampul, flakon vb. atıklar delici-kesici atıklar kutusuna, hastayla temas eden serum setleri, örtüler, spanç, solunum devresi vb. tıbbi atıklar, yırtılmaya dayanıklı ve çift kat kalınlığı 100 mikron olan ve her iki yüzeyinde "uluslararası biyotehlike" amblemi ile "DIKKAT TIBBI ATIK" ibaresi taşıyan kırmızı renkli plastik torbalara, kontamine olmamak şartıyla tıbbi malzemelerin ambalajları, kâğıt, karton atıklar, plastik içerikli malzemeler ve boşalmış serum torbaları geri dönüşüm atığı olarak mavi renkli plastik torbalara atılmaktadır. Hastanemizde de rutin uygulama bu şekildedir.

\section{İstatistiksel analiz}

Öncelikle tüm değişkenlerin tanımlayıcı istatistikleri yapıldı. Tanımlayııı istatistiklerde normal dağılan sayısal değişkenlerde ortalamaıstandart sapma bulundu. Ameliyat odası odalarından elde edilen toplam atık miktarı toplam olgu sayısına bölünerek olgu başı atık miktarı bulundu. Olgu başı atık miktarlarının karşılaştırımasında student t test kullanıldı. Kategorik değişkenlerin karşılaştırılması için ki-kare testi kullanıldı. $p<0.05$ anlamlı kabul edildi. Analizlerle IBM, SPSS.v20 kullanıldı.

\section{BULGULAR}

Eğitim öncesi ilk günün sonunda 22 ameliyat odası ve 3 uyandırma ünitesinden elde edilen anesteziye ait toplam atık miktarı alınan 57 hasta için $36.90 \mathrm{~kg}$ idi. Bunun 2.920 g delici-kesici, 26.290 g enfeksiyöz, $7.690 \mathrm{~g}$ ise geri dönüştürülebilir tıbbi atıklardı. Eğitim sonrası 22 ameliyat odası ve 3 uyandırma ünitesinden elde edilen toplam anesteziye ait toplam atık miktarı alınan 64 hasta için $43.36 \mathrm{~kg}$ idi. Bunun $3.565 \mathrm{~g}$ delici-kesici, $29.040 \mathrm{~g}$ enfeksiyöz ve $10.750 \mathrm{~g}$ ise geri dönüştürülebilir tıbbi atıklardı. Eğitimden sonra tıbbi atık miktarı azalırken ( $p=0.949)$, geri dönüşüm atığı ve delici-kesici atık miktarı istatistiksel olarak anlamlı oranda arttı $(p<0.001)$ (Tablo 1). Tıbbi atık bertaraf maliyeti \%1.6 oranında azaldı. 2021 yılı için belirlenen tıbbi atık bertaraf maliyeti, $3.50 \mathrm{TL} \mathrm{kg}^{-1}$ (KDV hariç)'dır. Pandemi döneminde hastanemiz ameliyat odasına ait yıllık tıbbi atık miktarı yaklaşık $107.023 \mathrm{~kg}$ olup, bu miktarın bertarafı için ödenen miktar, 374.580 TL (KDV hariç)'dir. Eğitimden sonra tıbbi atık bertaraf maliyetinin 5.993 TL (KDV hariç) azalacağı hesaplandı.

Tablo I. Eğitim öncesi ve sonrası tıbbi atık, geri dönüşüm atı̆̆ ve delici-kesici atık miktarı

\begin{tabular}{lccc}
\hline & $\begin{array}{c}\text { Eğitim öncesi } \\
\text { miktar } \\
\text { (gr/vaka başı) }\end{array}$ & $\begin{array}{c}\text { Eğitim sonrası } \\
\text { miktar } \\
\text { (gr/vaka başı) }\end{array}$ & p-değeri \\
\hline Tıbbi atk & $461.2 \pm 36.4$ & $453.8 \pm 33.1$ & 0.949 \\
Geri dönüşüm atı̆ı & $134.9 \pm 15.4$ & $167.9 \pm 19.1$ & $<0.001$ \\
Delici-kesici atk & $51.2 \pm 6.1$ & $55.7 \pm 6.3$ & $<0.001$ \\
\hline
\end{tabular}

Eğitime 26 anestezi uzmanı, 30 anestezi asistanı ve 37 anestezi teknisyeni olmak üzere toplam 93 kişi katıldı (Şekil 1).

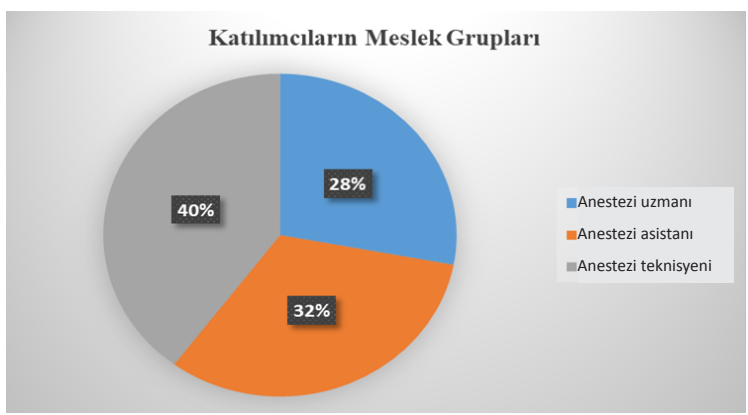

Şekil 1. Katılımcıların meslek grupları.

Katılımcıların \%69.9'nun eğitim gereksinimi hissettiğini, ancak \%51.3'ünün tıbbi atık eğitimi aldığını ve eğitim alma oranının anestezi teknisyeni grubunda daha fazla olduğunu gördük. Eğitime katılan grubun kullanılan eğitim videosu ile ilgili görüşleri Şekil 2'de verilmiştir.

Katılımcıların \%64.1'i eğitimden yararlandığını, \%40.8'i yeterli olduğunu, \%18.4'ü tıbbi atıklarla ilgili davranışlarını değiştirmeyeceğini, \%14.6'sı eksik olduğunu, \%11.7'si yüz yüze olmasını tercih ettiklerini belirttiler. 


\section{Katılımcıların eğitim videosu ile ilgili görüşleri (\%)}

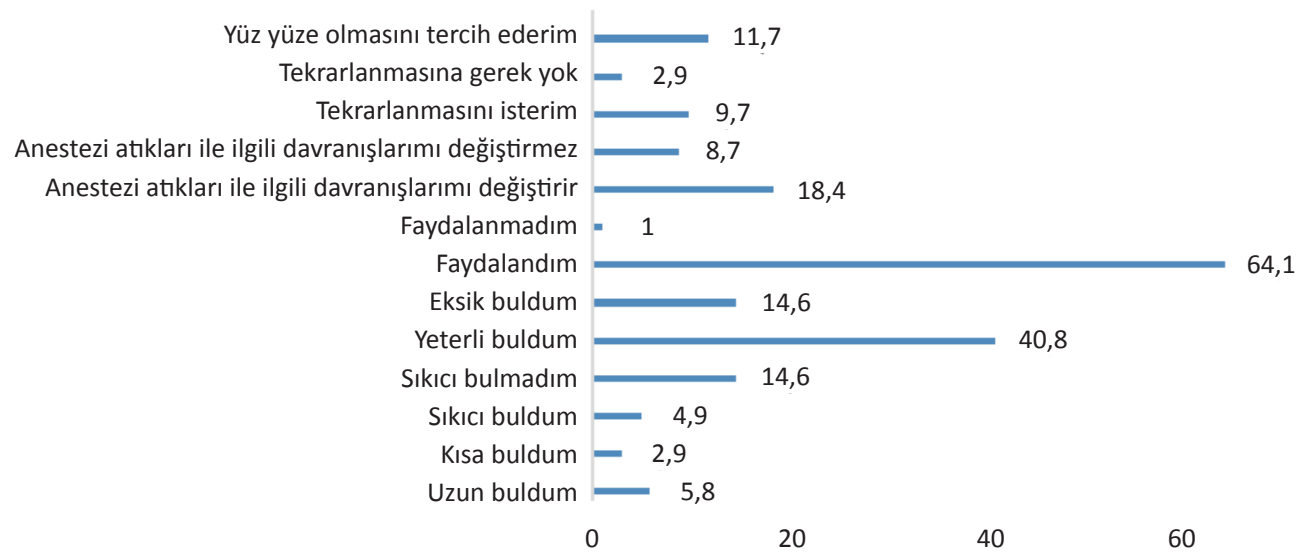

80

Şekil 2. Katılımcıların eğitim videosu ile ilgili görüşleri.

\section{TARTIŞMA}

Bu çalışmamızda, eğitim sonrası geri dönüşüm ve delici-kesici atık miktarı anlamlı oranda artmıştır. Tıbbi atık miktarı ise eğitim sonrası, istatistiksel olarak anlamlı olmasa da azalmıştır. Yüzde 51.3'ü daha önce eğitim alan grubumuzda tıbbi atık bertaraf maliyeti \%1.6 oranında azalmıştır.

Nüfus artışı, çevre dostu olmayan ekipmanlar ve tek kullanımlık malzeme kullanımının artışı ile tıbbi atık miktarı her yıl \%15 oranında artmaktadır. Tıbbi atık istatistikleri kapsamında ülkemizde, 2019 yıl sonu itibarıyla faaliyette olan 1.524 sağlık kuruluşundan toplanan tıbbi atık miktarı, 90 bin 920 ton olup, bir önceki yıla göre \%1.6 oranında artmıştır ${ }^{(5)}$. Bu miktarların artmaya devam edeceği düşünüldüğünde atıkların uygun bir şekilde toplanması ve taşınmasında özellikle sağlık çalışanlarının eğitim almaları ve aldıkları eğitimi uygulamalarına yansıtmaları önemlidir. Çalışmamızda, geri dönüşüm atık miktarının anlamlı artışı, tıbbi atık miktarının kısmen azalmış olması eğitimin yararlı olduğunun göstergesidir. Katılımcıların yarıdan fazlasının daha önce eğitim almış olması çalışanların tıbbi atıklar konusunda duyarlı olduğu sonucuna ulaştırabilir. Ancak, eğitimin bilinçlilik artışındaki önemi düşünüldüğünde, tıbbi atıklarla ilgili verilen hizmet içi eğitimler bir kez değil, değişiklikleri, yenilikleri içerecek şekilde sık aralıklarla yapılmalıdır ${ }^{(6)}$.

Hastanemizde toplam tıbbi atık miktarı yatak başına günde $2.24 \mathrm{~kg}$ olarak hesaplanmıştır. Eryılmaz ve ark.
(7) çalışmalarında, Türkiye geneli toplam tıbbi atık miktarı ise yatak başına günde $1.24 \mathrm{~kg}$ olarak hesaplanmıştır. Yaklaşık 2 kat olan bu artış, pandemi döneminde infeksiyon kontrol önlemleri nedeniyle artan malzeme kullanımı ile açıklanabilir.

Çevresel farkındalığın yaratılmasında, çevre bilincinin oluşturulmasında ve çevresel kirliliğini engellemede önemli bir yöntem de "kirleten öder" ilkesidir. 1983 tarih ve 2872 sayılı Çevre Kanunu'nun 9. maddesinin ilgili bendine göre, yarattığı kirliliğin bedelini kirleten kurum ve kuruluşlardan karşılanmasını ön gören cezai bir yaptırımdır. Bu ilke ile atıklardan kaynaklanan her türlü maliyetin atık üreticileri tarafından karşılanması amaçlanmaktadır. Türkiye'de "kirleten öder" ilkesinin doğrudan uygulandığı tek alan, tıbbi atıklardır ${ }^{(8)}$. 15.12.2020 tarih ve $20202 / 74$ sayıIı Ankara Valiliği Mahalli Çevre Kurulunun kararına göre sağlık kuruluşlarının ödeyeceği tıbbi atık bertaraf maliyeti, 2021 yılı için $3.50 \mathrm{TL} \mathrm{kg}^{-1}$ (KDV hariç) olarak belirlenmiştir. Belirlenen bu tutar 5216 sayılı Büyükşehir Belediyesi Kanunu'nun 7. maddesinin (i) fıkrasına göre "tıbbi atıklara ilişkin hizmetleri yürütmek, bunun için gerekli tesisleri kurmak, kurdurmak, işletmek veya işlettirmekten sorumlu olan büyükşehir belediyesine ödenir. Çalışmamızda, eğitimden sonra 1 günlük tıbbi atık miktarı \%1.6 oranında azalmıştır. Pandemi döneminde yaklaşık 107.023 kg yıllık tıbbi atık miktarı olan hastanemizde, eğitim ile tıbbi atık miktarında $1.712 \mathrm{~kg}$ ve bertaraf maliyetinde de 5.993 TL azalma sağlanabilmesi olası olacaktır. Ayrıca eğitimden sonra geri dönüşüm atık miktarı \%24.5 oranında artmıştır. 
Tıbbi atıklar, iyi yönetilip bertaraf edilmediğinde yüksek maliyetleri içen toplumsal bir sağlık sorununa neden olabilir (9). Tıbbi atıkların bertaraf maliyetleri genel atıkların bertaraf maliyetinden beş kat daha pahalıdır ${ }^{(10)}$.

Gelecek nesillere temiz ve yaşanabilir bir dünya bırakmak için sıfır atık prensibi ile atıkların kaynağında ve doğru bir şekilde ayrıştırılması önemlidir (11). Atık yönetiminin en önemli ilkesi atıkları kaynağında doğru olarak ayrıştırmaktır. Çalışanlara tıbbi atıklar konusunda farkındalıklarını artıracak eğitim programlarının uygulanması ile hem atıkların ayrıştıııması hem de geri dönüşüm konusunda olumlu davranışlar kazanmalarına yardımcı olunabilir. Bu konuda personel eğitimi, atık üreten kurum ve kuruluşların görev ve sorumluluğundadır. Covid-19 salgınının sağIık ve ekonomik etkilerinin yanında eğitim alanında da etkileri büyüktür. Çalışmamızda, daha önce eğitim alma oranı \%51.3 olup, ülkemizde yapılmış diğer çalışmalardaki oranlardan daha düşüktür (12). Çalışmamızın sonuçları hastanemiz Çevre Atık Yönetim Birimi ile paylaşılarak eğitim almayan grupların eğitim almaları ve diğer grupların da eğitimlerinin güncellenmesi sağlanacaktır. Pandemi sürecinde çalışanların iş yükünün artması, görevlendirmeler, çalışanlar arası bulaş riski ve infeksiyon kontrol önlemleri gibi nedenlerle yüz yüze eğitimler yapılamamış, ancak ilerleyen dönemlerde eğitici ve öğretenin farklı yerlerde olduğu, istenilen zamanda öğrenme ve öğretme faaliyetlerinin bilgi ve iletişim araçlarıyla gerçekleştirildiği uzaktan eğitim sistemleri önemli hâle gelmiştir.

Çalışmamızda, uzaktan eğitim aracı olarak "sıfır atık" projesi kapsamında hazırlanmış olan "tıbbi atıklar" video filmi katılımcılar ile paylaşılarak izlemeleri istenmiştir. Seçilen eğitim modeli ile ilgili katılımcıların görüşlerinin sorulduğu mini anket ile kullanılan yöntem ve içerik ile ilgili olarak daha sonraki eğitimlere rehber olması için kısa bir anket uygulanmıştır. Tıbbi atık yönetim planlarının başarıya ulaşmasını engelleyen nedenler arasında, eğitimlerin yetersizliği, gelişmekte olan ülkelerin kültürel yapısı, denetimlerin ve yönetim stratejilerinin yetersiz olması gösterilmiştir ${ }^{(13)}$. Katılımcıların \%64.1'i eğitimden yararlandığını, \%40.8'i yeterli olduğunu bildirseler de \%14.6'sı video içeriğinin eksik olduğunu, \%9.7'si eğitimlerin tekrarlanmasını, \%5.8'i videonun uzun olduğunu, \%11.7'si eğitimin yüz yüze olmasını tercih ettiklerini ifade belirttiler. Eğitim planlamalarının bu gereksinimler göz önünde bulundurularak yapılması olumlu sonuçları arttırabilir.

\section{SONUÇ}

Eğitim ile tıbbi atık bertaraf maliyetleri azaltılabilir. Anesteziyoloji ve reanimasyon kliniğinde, atık tasnifi ile ilgili farkındalık olmakla birlikte, tıbbi atık miktarının azaltılması için düzenli eğitimlerin yapılması gerektiği düşüncesindeyiz.

Etik Kurul Onayı: Dışkapı Yıldırım Beyazıt Eğitim ve Araştırma Klinik Araştırmalar Etik Kurul onayı (Karar No. 107/19, Tarih: 22.03.2021) alınmıştır.

Çıkar Çatışması: Yoktur.

Finansal Destek: Yoktur.

Hasta Onamı: Katılımcılardan onam alınmıştır.

Ethics Committee Approval: Dışkapı Yıldııım Beyazıt Education and Research Clinical Research Ethics Committee approval (Decision No. 107/19, Date: 22.03.2021) was received.

Conflict of Interest: None

Funding: None

Informed Consent: Consent were obtained

\section{KAYNAKLAR}

1. McGain F, White S, Mossenson S, et al. A survey of anesthesiologists' views of operating room recycling. Anesth Analg. 2012;114:1049-54. https://doi.org/10.1213/ANE.0b013e31824d273d

2. McGain F, Jarosz KM, Nguyen MN, et al. Auditing operating room recycling: A management case report. A A Case Reports. 2015;5:47-50. https://doi.org/10.1213/XAA.0000000000000097

3. Ali $\mathrm{M}$, Wang $\mathrm{W}$, Chaudhry $\mathrm{N}$, et al. Hospital waste management in developing countries: A mini review. Waste Manag Res. 2017;35:581-92. https://doi.org/10.1177/0734242X17691344

4. Foran P. Education report. ACORN: The Journal of Perioperative Nursing in Australia. 2015;28:28-30.

5. https://data.tuik.gov.tr/Bulten/Index?p=Tibbi-AtikIstatistikleri-2019-33900. (Yayım tarihi 27.11.2020, Sayı: 33900).

6. Cansaran D. Çalışanların tıbbi ttık bilinci düzeyini belirlemeye yönelik bir çalışma: Merzifon devlet hastanesi örneği. MANAS Sosyal Araştırmalar Dergisi. 2017;6:27184.

7. Eryılmaz H, Demirarslan KO. 2012-2018 yılları tıbbi atıklarının nüfus ile ilişkilendirilmesi ve mevcut bertaraf yöntemlerinin incelenmesi. ADYU Mühendislik Bilimleri Dergisi. 2020;13:89-103. 
8. Küçük A. Tıbbi atık yönetiminin ekonomisi. Sayıştay Dergisi. 2013;90:73-95.

9. Manyele SV, Lyasenga TJ. Factors Affecting Medical Waste Management in Low-Level Health Facilities in Tanzania. African Journal of Environmental Science and Technology. 2010;4:304-18.

https://doi.org/10.4314/thrb.v12i4.53362

10. Koo JK, Leong SI. Sustainability and shared smart and mutual-green growth (Scam-GG) in korean medical waste management. Waste Manag Res. 2015;33:410-
18. https://doi.org/10.1177/0734242X15574561

11. Çevre ve Şehircilik Bakanlığı, Çevre Yönetimi Genel Müdürlügü̈, Sıfır Atık El Kitabı, 2017, Ankara.

12. Akbolat $M$, Oğuz I, Cemile D, ve ark. Sağılık çalışanlarının tıbbi atık bilgi düzeylerinin değerlendirilmesi. ACU Sağlık Bil Derg. 2011:131-40.

13. Skenderovic I, Kalac B, Becirovic S. Environmental pollution and waste management. Balkan Journal of Health Science. 2015;3:2-10. 